\title{
TERTIARY LANGUAGE PLANNING AND CAREER DEVELOPMENT: CHALLENGES TO VIETNAMESE STUDENTS
}

\author{
Nguyen Thi Thom Thom*1, Bui Thi Ngoc Thuy ${ }^{2}$, Nguyen Duc An ${ }^{3}$ \\ 1. VNU University of Languages and International Studies, \\ Pham Van Dong, Cau Giay, Hanoi, Vietnam \\ 2. Hanoi University of Science and Technology, Dai Co Viet, Hai Ba Trung, Hanoi, Vietnam \\ 3. Taybac University, Quyet Tam, Sonla, Vietnam
}

Received 21 September 2019

Revised 08 May 2020; Accepted 23 July 2020

\begin{abstract}
Research in the field of English language education has shifted towards interrogating the real role of English in development across disciplines and countries. Vietnam English language policy, especially the National Foreign Languages Project (The NFL Project), have promoted English as a key success factor for Vietnamese students in the labour market as well as the well-being of the nation. This paper focuses on examining the notion of development which investigates the roles of English in Vietnamese tertiary students' employability. The researchers conducted 527 surveys with tertiary students in four university in the North Vietnam. Moreover, five students and three EFL tertiary instructors from each institution were selected to participate in a follow-up semi-structured interview $(\mathrm{N}=32)$. The results indicated students' limited level of confidence in both their English skills as well as career-related skills performed in English. In other words, students showed their lack of sufficient English for employability purposes. Aligning the research results with the promising and well-intended agendas of ELP and The NFL Project illuminates a clear mismatch between English and employability. In reality, the relationship between English language education and career development is highly complex and contested, which may influence students' full development in the long run. Towards the end, the paper offers suggestions for improving pedagogies, policies and practices to promote English as one of vital employability skills for multifaceted personal and national developments.
\end{abstract}

Keywords: Employability, English, Notions of Development, Tertiary Education

\section{Introduction}

The field of English language education (ELE) has been increasingly gravitated towards uncovering the role of English in enhancing students' successful employment (British Council, 2014), especially in many

\footnotetext{
Tel.: 84-912085632

Email: ThiThomThom.Nguyen@uon.edu.au; thomthomnguyenthi@yahoo.com
}

Asian countries where the diversification of the economy is increasing (Erling, 2014; Coleman, 2011). Leaners are required to learn English for desirable jobs and other social and political capitals (Aslam, Kingdon, \& Kumar, 2010; Grin, 2001; Ku \& Zussman, 2010). English for career development has been increasingly scrutinized in many countries such as Afghanistan, Bangladesh, India, Iran, Nepal, Pakistan, and Sri Lanka (Coleman, 
2011; Erling \& Seargeant, 2013). Aligning with this research trend, there is a great need to uncover the relationship between English language policy planning and Vietnamese tertiary students' employability in light of the recent extensive ELE reforms in Vietnam.

The influential expansion of English created momentum for various Vietnamese language policy shifts. These signification transformations greatly emphasize English as a competitive skill for both personal and national advancement. English is mandated for all students across the education levels. According to Nguyen (forthcoming), English education has been a key role for university students to harness success and privilege in the world of work.

Using a part of data of a recent longitudinal mixed-methods study in four universities in different regions across North Vietnam, this paper attempts to uncover the influence of the current Vietnamese English language policies in facilitating tertiary students' employability. The first data set was collected from September to December 2016. As many as 527 full-time undergraduate students in 20 different majors such as Nursery Education, Agriculture, Electro-mechanics, Information Technology, Biology-Chemistry, and Tourism (See Table 1) were invited to conduct a survey. Most of these students (97.9 \%) had sevenyear experience of learning English before enrolling in their current university. As the requirement of their institutional curriculum, they were required to take 14-credit-hour English courses during their first and second year. They had to meet such credit number for graduation. The data was enriched by a set of qualitative components, that is, followup semi-structured interviews with three EFL tertiary instructors and five students from each of the four universities $(\mathrm{N}=32)$. Each interview lasted from 15 to 20 minutes in the interviewee's suggested place and was in Vietnamese.

Table 1: General information on the research sites and participants

\begin{tabular}{|c|c|c|}
\hline University & $\mathrm{N}$ & Majors of students surveyed \\
\hline University 01 & 123 & $\begin{array}{l}\text { Sewing and Fashion Technology, Accounting, Economics, } \\
\text { Information Technology }\end{array}$ \\
\hline University 02 & 142 & $\begin{array}{l}\text { Physics, Mathematics, Mathematics-English Pedagogy, } \\
\text { Information Technology, Primary Education, Nursery } \\
\text { Education, Tourism, Vietnam Studies - Cultural Tourism }\end{array}$ \\
\hline University 03 & 132 & Agriculture, Economics, Electro-mechanics \\
\hline University 04 & 130 & $\begin{array}{l}\text { Economics, Biology-Chemistry, Mathematics, Information } \\
\text { Technology, Environment }\end{array}$ \\
\hline
\end{tabular}

Our preliminary data analysis addressed both EFL tertiary instructors' and students' perceptions of students' employability capacity. Students tended to show their low level of confidence in their English skills for employability as well as their illprepared command of career-related skills performed in English. Based on a review of the Vietnamese policy frame for tertiary ELE and employability and the notions of development, we discuss a mismatch between tertiary students' English language learning and employability. When current tertiary English programs fail to address students' needs for improving their English skills and soft skills required for their future careers such as debating and presenting in English, students can hardly take full advantage of their potentials, leading to questions of how they can build a secured foundation 
for their individual future and multifaceted developments, as well as how they can contribute to the goal of national development as targeted in the policy.

This paper is organised in two sections and shaped by three related arguments. We conduct a literature review of the current policy for tertiary ELE and employability, then discuss the application of the notions of development to Vietnamese language policies. Our further discussions address (1) misalignment between English language programs and employability, (2) misalignment between English language programs and career-related skills/soft skills in English, and (3) recommendations for facilitating students' employability, as presented in the sections that follow.

\section{Tertiary English language education and employability}

Since the time of Doi Moi (Renovation), significant political and economic shifts of the nation have called for various English language policy reforms in Vietnam. Doi Moi decentralises the state's power over private and local enterprises and foster multi-dimensional domestic and international collaborations to save the country from potential economic isolation after a ten-year period (1975-1985) under the socialist-oriented market economy and consequences of the US trade embargo. Doi Moi entails a less authoritarian, more multifaceted, multi-segmented model of governance (McCargo, 2004; Gainsborough, 2010) that has facilitated positive education and language reforms, including the rapidly growing demand to learn English in Vietnam (Bui \& Nguyen, 2016; Bui, Nguyen \& Nguyen, 2018). In 2008, the government launched The National Foreign Languages Project 2020 (hereafter referred to as The NFL Project) as a breakthrough in ELE and in national language reform by far. The NFL Project calls for a great demand for educating young Vietnamese citizens with English language proficiency in order to prepare for the strong development of both national and regional employability, as well as job competitions, especially in the context of the Association of Southeast Asian Nations' (ASEAN) economic integration (Government of Vietnam, 2008).

This policy offers great innovative strategies and action plans in ELE across all education levels and disciplines. To head for the English expansion and ELE reforms, the country has fostered a series of top-down transformational activities ranging from establishing national language testing centres, developing intensive English programs for both teachers and students, and providing intensive courses in English for specific majors such as engineering, tourism, business, finance, and technology (Plan 808/KG-BGDĐT, 2012). Regarding English language pedagogy, the national language policy reforms encourage studentcentred approaches in the English curriculum, stimulating students' creativity, autonomy and engagement in the learning process. The NFL project aims at the newly arisen context of a competence-based approach in assessment, which requires university graduates to achieve a certified command of English, equivalently ranging from B1 - CEFR for English nonmajors - to C1 for English majors (Bui, Nguyen \& Nguyen, 2017). Provision of English language programs and standardised qualifications at institutional levels target at catering for a greater demand of both domestic and international labour forces. This policy has also resulted in innovative curriculum and English language teacher education, especially re-evaluating EFL teacher training and re-training programs and provision of professional development for both in-service and pre-service EFL teachers (Nguyen, forthcoming). 
Albeit motivational and powerful, this policy seems ambitious in its objectives, thus placing a vague effect on the students' employability. After eight years of implementation, the NFL Project was reported not to successfully reach its initial short-term goals, with much less than $50 \%$ of the set tasks being fulfilled. Representatives of the Ministry of Education and Training admitted that most English language teachers were understandardised. Teachers' poor instructional quality seemingly resulted in students' poor English competencies, which could hardly satisfy the purposes of employability (Luong, 2016). The goals of the NFL Project; accordingly, have been re-considered with an extended timeline up to the year 2025, with newly lesson-drawn objectives and updates aiming to boost English for employability for $100 \%$ of non-English major graduates, $90 \%$ of vocational students, and $60 \%$ of employees in public sectors (Hoang, 2016). These facts call for a stronger evaluation and greater emphasis of the connectedness between ELE education and employability, stated in an official adapted version of The NFL Project called Project 2025, issued by the Vietnamese government in late December 2017. Grounded on The NFL Project in terms of general goals, Project 2025 aims to address three major aspects as follows: (1) renovating foreign languages education in the national education system, continuing to implement new foreign language programs at all levels, and improving learners' foreign languages competence to meet the study and work demand; (2) strengthening the competitiveness of human resources in the integration period, contributing to the purpose of national development; and (3) establishing a nationwide foreign language foundation for general education in 2025 (Government of Vietnam, 2017).

While the intensive focus on English and ELE has emerged both in Vietnamese contexts and globally, a wide range of researchers in the field express their great concern for the significance of English for tertiary students' career development (Ferguson, 2013; Phillipson, 2012; Seargeant \& Erling, 2013; Tollefson, 2013). Research into the impact of ELE indicates that the notion of English in development is contested and controversial. Thus, for an insight into the role of the current ELP to the students' development, we present the notion of development as a theoretical foundation for our study.

\section{Applying the notion of development to Vietnamese English language policies}

The socio-economic and political developments have greatly transformed the notion of development which is now to be considered as contested, inclusive, and multilayered (Coleman, 2010). Aspects such as social and economic fulfillments, good governance, human rights, welfare, freedoms of social and economic engagement, employability, health care, and civil rights have become an epi-center in development (e.g., Coleman, 2011; Bruthiaux 2002). Development addresses the nation's ability to accommodate voices and choices and people's participation in social and economic planning and interventions (Seargeant \& Earling, 2013).

Development and education have an intrinsic linkage as education promotes the knowledge economy for national development. Specifically, language proficiency and literacy programs set a solid foundation for advancing a skilled and interdisciplinary work force for development, which significantly fosters wideranging economic and social advancements, giving rise to high income, comprehensive social welfare, and human right protections (Coleman, 2010; Kirkpatrick \& Sussex, 2012). Similarly, English is considered to possess a vital literacy tool for improving socio-economic and cultural capital (Seargeant \& Earling, 2013).

Notions of development offer a crucial foundation for the interpretation of employability development in the 
current Vietnam English language policies. Development, as defined in this paper, offers a comprehensive insight into not only economic development but also a process to secure one's privileges and rights in various aspects of life including health, education, and social well-being. The concept of development is utilized to refer to implications as to whether the current English language policies prepare students with sufficient linguistic competencies for successful employment and personal advancements or whether such English language policies greatly bar them from employability capacities. The paper assumes that should tertiary students be equipped with good English language skills, they can be better prepared for their future employability and development. Looking from a nuanced perspective, students' English language proficiency can facilitate them to gradually gain an access to successful employment and social, educational, and economic negotiations. We further discuss this assumption in the sections of findings and discussion that follows.

\section{Misalignment between English language programs and employability}

A key finding of our research is that while students were all required to attend English courses at their institution, they did not benefit much from the institutional English language programs for employability skills. The majority of tertiary students (from over $70 \%$ to $80 \%$ ) were not confident of their abilities to accomplish various activities in English such as listening to different topics (14.04\% and $67.74 \%$ for "very unconfident" and "unconfident", respectively), collecting information $(29.41 \%$ and $48.01 \%)$, answering phone inquiries $(20.49 \%$ and $58.44 \%$ ), and ability to understand human resource documents $(22.96 \%$ and $54.65 \%)$ in English (See Appendix A). Students also lacked confidence in handling other activities required at their future workplace including understanding schedules, reading comprehension, reading information on the company websites, and creating documents, letters, reports, and invoices in English.

Justifications for these tertiary students' limited English for employability skills could include a range of factors from the institutional English programs to the students' learning related issuses. Both the EFL tertiary instructors and students interviewed shared that students could not communicate in English effectively or perform different tasks in English because communicative teaching approach is almost absent in their institutional curriculum. One student of economics major indicated a reality of his English:

I am not confident with my English for employability because our English program in Vietnam does not focus on educating students for communicative skills but on grammar and theories. Moreover, I did not learn English systematically when I was young, so I am afraid of re-learning it. (Em không tụ tin ... vì chuoong trình Tiếng Anh ở [nước] mình không tập trung vào các kỹ năng giao tiếp mà chỉ toàn ngũ pháp và lý thuyết. Em không được hoc Tiếng Anh bài bản tù̀ bé nên em ngại học lại.)

A EFL tertiary instructor in Agriculture major commented that even when the communicative approach was mentioned in their English program, there were no details of specific communicative tasks and assessments. What the teachers and students could mostly do in the classroom was focusing on the reading tasks, completing the vocabulary and grammar exercises. The instructor further explained that this English program could be most suitable to students of low levels, and other factors such as the time allotment in the syllabus and big class size did not allow for promoting students' communicative skills. 
Many other students faced the same challenge in communicating in English because they lacked both confidence and motivation, and they found it hard to respond naturally. Consequently, students did not own a sense of preparedness for any job environments which require English. A student majoring in Math explained his pessimistic perspective: "I am not confident with my English for job related purposes in the future because my English skills are not enough for communication"/ Em chẳng thấy tự tin chút nào với vốn Tiếng Anh để làm việc sau này vì đến tiếng Anh co bản em cũng chẳng đủ cho giao tiếp thông thuờng.) $\mathrm{He}$ stated that:

"I have learnt English for nearly ten years, but not continuously. Sometimes, I just revised some English grammar for tests and examinations. When I attend my English class, I mostly sit silently, try to copy words or anything the teacher writes on the board. I cannot remember all the words and I hardly speak out any sentences in English. I can only do some word-by-word translation from English to Vietnamese. I'm ashamed of my English and my English language learning but I don't like learning English. At the moment, I feel it is not useful for my teaching Maths in the future." (Em học Tiếng Anh gần 10 năm nay, nhưng mà không liên tuc. Đôi khi em chỉ học ôn một chút ngũ pháp để chuẩn bị cho thi củ kiểm tra. Khi đi họ giò Tiếng Anh, em chủ yếu ngồi yên, cố chép tù̀ và nhũng gì thầy cô viết trên bảng vào vở cho có. Em chẳng nhớ nổi các tù đó và em chẳng nói nổi câu Tiếng Anh nào ra hồn. Em chi dịch tùng tù một tù̀ Tiếng Anh sang Tiếng Việt. Em xấu hổ với vốn Tiếng Anh và việc học Tiếng Anh của mình, nhung em chẳng thích hoc Tiếng Anh. Giờ em thấy nó chura hưu ich cho nghề nghiệp dạy Toán của em sau này.)

The students' responses greatly coincided with the EFL tertiary instructors' perspectives that their students' English competence was not sufficient enough for future employability.
These tertiary instructors expressed their worry about students' capability to function at an English-based workplace. They reflected that most students admitted their poor command of English, and "only a small number of students have been prepared with enough English knowledge and skills for English-related jobs"/ chi số it sinh viên đủ kiến thức và kỹ năng Tiếng Anh chuẩn bị cho các công việc có Tiếng Anh sau này). As a matter of fact, almost all students are supposed to go back to their university or attend other language courses to "relearn English" to meet their job requirements. An English instructor in IT major mentioned a fact that at the beginning of any English course, she often advised her students to make effort in learning English by both following the institutional program and attending extra classes. She emphasized "The institutional program cannot fully facilitate your English improvement, you need to invest more to cope with job requirements in the near future." (Chương trình hoc ở truòng không đủ giúp các em tiến bộ với Tiếng Anh đâu. Các em cần đầu tu hơn nữa để bắt kịp với yêu cầu nghề nghiệp trong tuoong lai không xa.) Another fact was that her students often 'rushed' to her for advice when they nearly completed the English program at the university or before graduation. These students tended to suffer from the pressure of having an urgent English proficiency certificate for their job application.

It seems that the English programs played an invisible role in helping both the EFL tertiary instructors and students feel confident about students' English for employability. Such uncertainty was rather complex on multiple issues including program development, students' unsystematic English language education, lack of environment to practise communicative English as well as students' low motivation and poor awareness to learn the subject. 


\section{Misalignment between English language programs and career-related skills}

Similar to disconnect between English language programs and employability, institutional English language programs seemed to mismatch with the set task of preparing for students' career-related skills performed in English. To be specific, students' level of certainty about performing career skills in English was rather low. Student participants indicated they were largely incapable of debating ( $25.81 \%$ and $54.08 \%)$, solving problems $(22.2 \%$ and $55.22 \%)$, and working with people worldwide $(26.57 \%$ and $50.47 \%$ ). Apart from these activities, a majority of students were unable to perform many other career-related skills including interpersonal skills, using technology, leadership, and searching for scholarships in English (See Appendix A)

Both EFL tertiary instructors and students indicated that various challenges hindered them from achieving the aim of improving students' above career-related skills in English. While interviewed instructors reflected that students "are idle, inactive, lazy, demotivated" and "just smile, do not want to talk", many students realised their problems with the lack of vocabulary to express their ideas and their fear of making mistakes. Consequently, students' performance of skills such as problem solving and group work performed in English only ranged from insufficient to average level. A nurse - major instructor's response stated:

Generally speaking, the students seem inactive and demotivated. Even when they know that English is important for employability, they do not seem to worry much. They do not try hard enough to improve their skills. Many do not complete the homework, prepare for the lesson or actively engaged in in-class activities. They think the English program at the university is just a subject. They wish to learn less yet achieve higher scores. (Sinh viên nói chung là thu động và thiếu động lực. Kể cả khi biết tiếng Anh rất quan trọng cho nghè nghiệp sau này, duờng nhu các em cũng không tỏ ra lo lắng lắm. Các em chẳng cố gắng mấy để cải thiện kỹ năng. Nhiều em không làm bài về nhà, không chuẩn bị bài mới hay không tích cực tham gia các hoạt động trên lớp. Các em nghĩ chuơng trình học Tiếng Anh ở trưòng [đại học] chỉ là mọt môn học).

One EFL tertiary instructor in agriculture major reflected that the students could not work in groups effectively so sometimes she and her colleagues had to require them to prepare beforehand the topics in both Vietnamese and English. She observed that the students were not willing to talk or discuss. With problem solving skill, students did not even try to brainstorm or think because they got familiar with lecturers providing options for them. Therefore, "they can't think about solutions and even if they have some solutions, they are unable to express them in English". (Vi vây, sinh viên không thể nghĩ ra giải pháp và kể cả khi có giải pháp, ho cũng chẳng biết diễn đạt thế nào bằng Tiếng Anh).

Addressing the students' presentation skills, this EFL tertiary instructor further commented that "students do not want to talk because of their limited vocabulary range. They speak slowly and have many repetitive phrases or sentences." (Sinh viên không muốn tham gia vì vốn tù hạn hẹp. Các em nói rất chậm và thuờng hay lạp lại các cum tù và câu). Besides, not all students could have opportunities to practise their presentation skills because of limited time and lack of guidelines in the course syllabus.

Students also expressed their deficiency in communicating in English with people within and outside of their future work 
setting. They acknowledged that both their English and communicative skills were inadequate, so they might hesitate or avoid talking to others. When required to speak, they tended to feel nervous and even resorted to broken language or the type of minimal English that they had picked up after years of learning. Sharing the same perspective, almost all the instructors cast doubt on the students' ability to communicate in English in their work setting. An EFL tertiary instructor in business management major voiced his opinion:

Although students may have learnt English for many years, their English does not always improve when they reach tertiary levels. They become less open to speak. They are shy and cannot express themselves clearly and precisely. I think students can only function some simple conversations in English. Only a small number of students can work effectively with people in the region and worldwide in English. (Dù sinh viên có thể học tiếng Anh nhiều năm nhưng trình Tiếng Anh cuả các em không phải lúc nào cũng tiến bộ khi lên đại hoc. Các em it 'open' hơn khi phải nói, ngại và không biết cách diễn đạt ý của mình rõ ràng và chuẩn xác. Mình cho rằng sinh viên chỉ nói được vài dạng hội thoại co bản bằng Tiếng Anh. Chỉ có số it sinh viên có thể làm việc hiệu quả bằng Tiếng Anh với người trong khu vực và quốc tế).

Students' lack of English competencies may lead to their inability to perform soft skill activities such as debating, presentation, working in groups, and showing their role as a leader in English effectively. The justifications can be students' English learning and EFL teaching pedagogies embedded in their English programs. Thus, it may also be implied from this study that ways of doing education at the tertiary level should be addressed. Details of such implications will be presented in the final part of this paper.

\section{Recommendations for facilitating students' employability}

Several suggestions from both the students' and lecturers' perspectives were proposed to enhance students' English as an attribute critical to employers. On that ground, our study further recommended a great emphasis on appropriate pedagogy, innovative language programs, and the provision of skill-based courses for employability. This can better suit students' potentials and needs and capture their attention to learn English successfully. Discussing how to improve institutional language program, a student voiced that: 'We want to learn English systematically from basic to advanced levels, following a clear guideline. We are ready to start from scratch." (Chúng em muốn học Tiếng Anh hệ thống tù cơ bản đến nâng cao, the chi dẫn rõ ràng. Chúng em sã̃n sàng hoc [laị] tù̀ đầu.) Another student majoring in Electro-Mechanics added that they need practise and drill their communicative skills in different contexts. Mentioning the current university programs, both these student participants agreed that they would like to be provided with more practical and interesting lessons and that teachers should apply "updated" teaching methods. Of a particular note, offering appropriate teaching methods with the performance-based approach to suit students' needs and ages was highly emphasized. Further, such methods may equip students with soft skills which enable them to function more successfully and encourage their active learning performance.

Along with the improvement in quality of instruction, teaching communicative skills, namely listening and speaking skills should be oriented and spent more time to redress the balance of all four language skills because the time allocated for the current English language course at secondary levels was mainly for reading and some basic writing. There should be more extracurricular activities such as 
English clubs and Guest speakers with the participation of invited employers which can provide students a wide range of opportunities for both their English and English-related skill enhancement. More importantly, inclusion of diverse soft skill courses and job searching workshops in current institutional English programs would better prepare students for their future employability. Many of the student interviewees expressed their need to be provided with more specific and hands-on skill courses. One student emphasised that they were in dire need of practising soft skills such as communication, debating and technology.

In addition, according to the interviewed EFLtertiary instructors and students, a program development division in each university and/ or an employability counselling unit should be established to focus and incorporate companies' demands with the learning outcomes. As a result, the lecturers' burden of time constraints can be alleviated because this division can provide them with "employment scenarios" and information on the labour market to be included in their teaching. To the suggestion of a lecturer of automobile major, English for job interviews should be added to her institutional curriculum and assessment tools should be improved to better the outcomebased assessment. To illustrate, while the four language skills are integrated into teaching and learning process to enable students to be more confident and successful in real-life situations, the formative assessment focusing on students' learning process should be used as the main tool instead of the summative which is widely used. What is more, students' language communicative competence should be officially tested, instead of the current lexico-grammar oriented exams. To a lecturer of Economics, both teachers and test designers need to redress the balance of all four skills with the association with checklists of "I can" descriptors.
Collected data figured out that students' attitudes and reactions to the importance of English language in their future jobs had resulted in their poor attainment and almost illiteracy in English after over seven years of academic exposure to English at secondary levels. The most common explanations provided were that English seemed to be an impossible subject for its difficulty, there were no improvements in their language competence, and their motivation of English language learning is too low as they lived in remote areas with no or very little contact with English speakers and they learned English for doing nothing. As such, both the importance of learning English and promoting the habit of learning English among students should be highlighted in a persistent and systematic manner so that students' employability skills can be ultimately enhanced.

The quality improvement of English language teaching and learning would be extremely challenging and complex in the context of this study since it requires the involvement of managers, policy makers and educators of all levels. Such recommendations further imply that many aspects including teaching methods/quality of instruction, program development, curriculum design, students' needs, and employers' requirements need to be taken into serious consideration to issue appropriate and feasible policies, decisions and requirements, hence, aiming at improving English for students' career development.

\section{Discussion and conclusion}

The study aims to address the underresearched students' English language skills for employability. The results show the increasingly limited role of English in fostering students' successful employment because the English language policies largely fail to equip students with good English 
competency. Students seem to be unable to use their English for as one of the tools for employability demands set by employers, their society, and beyond. English is obviously, unable to function as a linguistic capital, sanctioning students with power and dispositions in their social world.

The results further suggest that the English programs seem to be loosely structured and administered. Such policies could de-facto stealing students' time while de-motivating their passion towards having solid English language skills. In other words, such language programs in this context may close students' multiple opportunities later in life when teaching and learning activities still seems to be incomprehensive, contested, and controversial.

The study also aims at providing some rigorous recommendations for enhancing students'English and employability capacities.

First, a systematic English education from primary level onwards is recommended. This is because many students in this study possess a poor English proficiency although they have learned English for such a long time. They need to have a solid and systematic English program from lower levels, which could set a good foundation for their English in tertiary education. University students face a doubled burden because they have to learn both their major and English. However, they seem to struggle with English rather than other subjects. This is the reason why students were not confident in performing a job using English.

Second, students need to be guided to a mindset of life-long learning when it comes to learning a language. Learning language takes a tremendous amount of time and effort and they need to be mentored to learn in a strategic and persistent manner. We suggest lecturers to teach students learning how to learn, selfstudying while mobilizing the advancement of technology in learning English (Bui, 2016). It is vital to take advantage of abundant online materials for their English and soft skill improvements (Darling-Hammond, 2010).

Finally, we need a collaborative and supportive effort between universities and employers. Career development divisions work with employers to tailor English programs which address employers' demands regarding skills and knowledge needed. Such divisions foster a ground for policy makers, lecturers, and administrators to structure and develop diverse courses to boost students' successful employment (Ku \& Zussan, 2010; Lee, 2012). Career-orientation workshops and internship programs should be promoted to better prepare for labour market requirements while enriching students' hands-on experiences and relationships with employers (Pooja, 2013). We highly agree with Bui, Nguyen, and Nguyen (2018; p.65) to argue that "English as employability skill for development should be developed in a systematic, collaborative, diverse, and conscientious approach to meet everdemanding requirements of both domestic and international employers." We need tremendous effort from multiple stakeholders: the students themselves, policy makers, the tertiary governance, and employers to develop a sustainable workforce. Successful employment contingents on comprehensively and rigorously structured language policy planning and practices.

\section{References}

Aslam, M., De, A., Kingdon, G. \& Kumar, R. (2010). Economic Returns to Schooling and Skills - An Analysis of Pakistan. Cambridge, UK: University of Cambridge.

Bruthiaux, P. (2002). Hold your courses: Language education, language choice, and economic development. TESOL Quarterly, 36(3), pp. 275-296.

Bui, T. T. N., \& Nguyen, T. M. H. (2016). Standardizing English for educational and socio-economic betterment: A critical analysis for English language policy reforms in Vietnam. In R. Kirkpatrick 
(Ed.), English language education policy in Asia (pp. 363-388). Switzerland: Springer International Publishing.

Bui, T. N. T., Nguyen, T. T. T., \& Nguyen, D. A. (2017). English as a Key Employability Capacity: Perspectives from Vietnamese Students and Lecturers. Language Education in Asia, 8(2), pp. 144-156.

Bui, T. N. T., Nguyen, T. T. T., \& Nguyen, D. A. (2018). Vietnamese higher education language planning and university students' career development. In J. Albright (Ed.), English Tertiary Education in Vietnam (pp.54-67). London: Routledge.

British Council. (2014). Annual report 2013-14. London: British Council

Coleman, H. (2010). The English Language in Development. London: British Council.

Coleman, H. (Ed.). (2011). Developing countries and the English language: Rhetoric, risks roles and recommendations. London: British Council.

Darling-Hammond, L. (2009). The flat world and education: How America's commitment to equity will determine our nation's future. New York: Teachers College Press.

Darling-Hammond, L. (2010). Teacher Education and the American Future, Journal of Teacher Education, 61(35). Doi: 10.1177/0022487109348024

Erling, J. E., \& Seargeant, P. (2013). English and development: Policy, pedagogy, and globalization. Bristol, UK: Multilingual Matters.

Erling, E. J. (2014). The roles of English in skills development in South Asia: Policies, interventions and existing evidence. London: British Council.

Ferguson, G. (2013). English, development and education: Charting the tensions. In E. Erling \& P. Seargeant (Eds.), English and development: Policy, pedagogy, and globalization (pp. 21-44). Toronto, Canada: Multilingual Matters.

Gainsborough, J. (2010). Vietnam: Rethinking the state. London and New York: Zed Books and Silkworm Books.

Government of Vietnam. (2008). Decision 1400/QDTtg on the approval of the project "Teaching and Learning Foreign Languages in the National Education System, Period 2008-2020".

Government of Vietnam. (2017). Decision 2080/QD-Ttg on the refresh of the project "Teaching and Learning Foreign Languages in the National Education System, Period 2017-2025".

Grenfell, M. (2012). Bourdieu, language and education. In M. Grenfell, D. Bloome, C. Hardy, K. Paul, K. Rowsell, \& B. Street (Eds.), Language, ethnography and education: Bridging new literacies and Bourdieu (pp. 50-70). New York: Routledge.

Grin, F. (2001). English as economic value: facts and fallacies. World Englishes, 20(1), pp. 65-78.
Hamid, O. (2015). English and employability, mobility and development. Retrieved from www. britishcouncil.org.bd/sites/default/files/bc_think_ piece obaid hamid 08 10 2015.pdf

Hanks, W. F. (2005). Pierre Bourdieu and the practices of language. Annual Review of Anthropology, 34(1), 6783. doi:10.1146/annurev.anthro.33.070203.143907

Hoang, P. (2016). Đề án ngoại ngũu gần 9400 tỷ sau 8 năm làm được nhũng gì. Retrieved from http://vnexpress. net/tin-tuc/giao-duc/de-an-ngoai-ngu-gan-9-400-tysau-8-nam-lam-duoc-nhung-gi-3470788.html

Kirkpatrick, A., \& Sussex, R. (2012). English as an international language in Asia: Implications for language education. New York: Springer.

Kramsch, C. (2008). Pierre Bourdieu: A biographical memoir. In J. Albright \& A. Luke (Eds.), Pierre Bourdieu and literacy education (pp. 33-49). New York: Routledge.

$\mathrm{Ku}, \mathrm{H}$., \& Zussman, A. (2010). Lingua franca: The role of English in international trade. Journal of Economic Behavior and Organization, 75(2), pp. 250-260.

Lee, C. G. (2012). English language and economic growth: Cross-country empirical evidence. Journal of Economic and Social Studies, 2(1), pp. 5-20.

Luke, A. (2008). Using Bourdieu to make policy: Mobilizing community capital and literacy. In J. Albright \& A. Luke (Eds.), Pierre Bourdieu and literacy education (pp. 347-361). Malwah, NJ: Lawrence Erlbaum Associates.

Luong, H. N. (2016). Đề án ngoại ngũ quốc gia 2020 thất bai vì đâu. Retrieved from http://baoquocte. vn/de-an-ngoai-ngu-quoc-gia-2020-that-bai-vidau-39673.html

McCargo, D. (2004). Introduction. In D. McCargo (Ed.), Rethinking Vietnam (pp. 1-12). London: Routledge.

Nguyen, T. T. T. (forthcoming). Professional development: Vietnamese EFL teacher educators' perceptions and experiences. (Doctoral Dissertation), The University of Newcastle, Australia.

Phillipsons, R. (2012). Linguistic imperialism alive and kicking. The Guardian. Retrieved from www. guardian.co.uk/education/2012/mar/13/linguisticimperialism-english-language-teaching

Plan 808/KH_BGDDT. (2012). Kế hoạch triển khai đề án ngoại ngũ 2020 trong các co sở giáo duc đại họ giai đoạn 2012-2020. Retrieved from www.moet. gov.vn/?page $=6.21 \&$ script $=\% 20$ congvan\&namxly $=-1$

Pooja, B. (2013). English for employability-A challenge for ELT faculty. Research Journal of English Language and Literature, 1(3), pp. 350-353.

Seargeant, P., \& Erling, E. J. (2011). The discourse of 'English as a language for international development': Policy assumptions and practical challenges. In H. Coleman (Ed.), Dreams and 
realities: Developing countries and the English language (pp. 248-267). London: British Council.

Seargeant, P., \& Erling, E. J. (2013). Introduction:

English and development. In E. Erling \& P.

Seargeant (Eds.), English and development: Policy, pedagogy, and globalization (pp. 22-45). Toronto, Canada: Multilingual Matters.

Tollefson, J. W. (2013). Language policies in education: Critical issues (2nd ed.). New York: Routledge.

\title{
ĐỊNH HƯỚNG NGÔN NGŨ VÀ PHÁT TRIỂN NGHỀ NGHIẸP: THÁCH THỨC VỚI SINH VIÊN VIẸTT NAM
}

\author{
Nguyễn Thị Thơm Thơm ${ }^{1}$, Bùi Thị Ngọc Thủy², Nguyễn Đức Ân ${ }^{3}$ \\ 1. Đại học Ngoại ngũu, Đại học Quốc gia Hà Nội, \\ Phạm Văn Đồng, Cầu Giấy, Hà Nội, Việt Nam \\ 2. Đại học Bách khoa Hà Nội, Đại Cồ Việt, Hai Bà Trung, Hà Nội, Việt Nam \\ 3. Đại học Tây Bắc, Quyết Tâm, Son La, Việt Nam
}

Tóm tắt: Xu hướng nghiên cứu trong lĩnh vực giảng dạy tiếng Anh những năm gần đây tập trung nhiều vào vai trò thực tế của tiếng Anh trong sự phát triển của các ngành nghề và các quốc gia. Chính sách ngôn ngữ về tiếng Anh ở Việt Nam, đặc biệt là Đề án Ngoại ngữ Quốc gia coi tiếng Anh như là chìa khóa thành công của sinh viên Việt Nam trong thị trường lao động cũng như sự phát triển bền vững của đất nước. Nghiên cứu này nhìn nhận lại các quan điểm về phát triển trong đó chú trọng đến vai trò của tiếng Anh trong việc phát triển các kĩ năng nghề nghiệp của sinh viên đại học Việt Nam. Khảo sát được thực hiện với 527 sinh viên hiện đang theo học tại 4 trường đại học ở khu vực phía Bắc. Sau đó, 5 sinh viên và 3 giảng viên tiếng Anh ở mỗi trường được lựa chọn để tham gia phỏng vấn $(\mathrm{N}=32)$. Kết quả thu được cho thấy sinh viên không tự tin vào kĩ năng tiếng Anh cũng như các kĩ năng nghề nghiệp khác cần sử dụng tiếng Anh. Nói cách khác, sinh viên thiếu kĩ năng tiếng Anh phục vụ cho mục đích công việc. Đối chiếu kết quả nghiên cứu với lộ trình và mục tiêu của Đề án Ngoại ngữ Quốc gia có thể thấy rõ sự khập khiễng giữa năng lực tiếng Anh và các kĩ năng nghề nghiệp. Thực tế, mối quan hệ giữa giảng dạy tiếng Anh và sự phát triển nghề nghiệp khá phức tạp và gây nhiều tranh cãi, điều này về lâu dài ít nhiều ảnh hưởng tới sự phát triển toàn diện của người học. Từ những vấn đề quan trọng được chỉ ra từ kết quả nghiên cứu, nhóm tác giả đề xuất một số giải pháp liên quan đến việc phát triển các chính sách và cách thức thực hiện nhằm nâng cao vai trò và hiệu quả của tiếng Anh như là kĩ năng nghề nghiệp cần thiết đối với sự phát triển toàn diện của mỗi cá nhân và đất nước.

Tù khóa: kĩ năng làm việc, tiếng Anh, quan điểm về phát triển, giáo dục đại học 
Appendix A - Students' English skills and English as an employability skill

\begin{tabular}{|c|c|c|c|c|c|c|c|c|c|c|}
\hline & \multicolumn{2}{|c|}{$\begin{array}{c}1-\text { Very } \\
\text { unconfident }\end{array}$} & \multicolumn{2}{|c|}{$\begin{array}{c}2- \\
\text { Unconfident }\end{array}$} & \multicolumn{2}{|c|}{$\begin{array}{c}3- \\
\text { Confident } \\
\end{array}$} & \multicolumn{2}{|c|}{$\begin{array}{l}4-\text { Very } \\
\text { confident }\end{array}$} & \multicolumn{2}{|c|}{$\begin{array}{l}5-\text { Not } \\
\text { sure }\end{array}$} \\
\hline & $\mathrm{n}$ & $\%$ & $\mathrm{~N}$ & $\%$ & $\mathrm{n}$ & $\%$ & $\mathrm{n}$ & $\%$ & $\mathrm{n}$ & $\%$ \\
\hline \multicolumn{11}{|c|}{ I English skills } \\
\hline 1 Ability to collect information & 155 & 29.41 & 253 & 48.01 & 72 & 13.66 & 8 & 1.52 & 39 & 7.40 \\
\hline $\begin{array}{l}2 \text { Ability to listen to different } \\
\text { topics }\end{array}$ & 74 & 14.04 & 357 & 67.74 & 51 & 9.68 & 7 & 1.33 & 38 & 7.21 \\
\hline 3 Ability to communicate & 108 & 20.49 & 281 & 53.32 & 60 & 11.39 & 26 & 4.93 & 52 & 9.87 \\
\hline $\begin{array}{l}4 \text { Ability to answer phone } \\
\text { inquiries }\end{array}$ & 108 & 20.49 & 308 & 58.44 & 59 & 11.20 & 10 & 1.90 & 42 & 7.97 \\
\hline 5 Ability to do presentations & 115 & 21.82 & 253 & 48.01 & 80 & 15.18 & 22 & 4.17 & 57 & 10.82 \\
\hline 6 Ability to introduce yourself & 62 & 11.76 & 229 & 43.45 & 161 & 30.55 & 22 & 4.17 & 53 & 10.06 \\
\hline $\begin{array}{c}7 \text { Ability to answer interview } \\
\text { questions }\end{array}$ & 113 & 21.44 & 285 & 54.08 & 59 & 11.20 & 19 & 3.61 & 51 & 9.68 \\
\hline 8 Ability to comprehend readings & 86 & 16.32 & 236 & 44.78 & 127 & 24.10 & 18 & 3.42 & 60 & 11.39 \\
\hline $\begin{array}{l}9 \text { Ability to understand timetables } \\
\text { and job-related agendas }\end{array}$ & 96 & 18.22 & 264 & 50.09 & 86 & 16.32 & 13 & 2.47 & 68 & 12.90 \\
\hline $\begin{array}{l}10 \text { Ability to read information } \\
\text { regarding companies online }\end{array}$ & 86 & 16.32 & 286 & 54.27 & 94 & 17.84 & 17 & 3.23 & 44 & 8.35 \\
\hline $\begin{array}{l}11 \text { Ability to understand human } \\
\text { resource policies }\end{array}$ & 121 & 22.96 & 288 & 54.65 & 47 & 8.92 & 12 & 2.28 & 59 & 11.20 \\
\hline $\begin{array}{l}12 \text { Ability to create documents, } \\
\text { for example, letters, instructions, } \\
\text { annoucements, forms, and email }\end{array}$ & 112 & 21.25 & 271 & 51.42 & 66 & 12.52 & 10 & 1.90 & 68 & 12.90 \\
\hline \multicolumn{11}{|c|}{ II English as an employability skill } \\
\hline $\begin{array}{l}13 \text { Ability to work with } \\
\text { colleagues in groups }\end{array}$ & 105 & 19.92 & 281 & 53.32 & 71 & 13.47 & 13 & 2.47 & 57 & 10.82 \\
\hline 14 Ability to solve problems & 117 & 22.20 & 291 & 55.22 & 55 & 10.44 & 9 & 1.71 & 55 & 10.44 \\
\hline $\begin{array}{l}15 \text { Ability to share, collaborate, } \\
\text { support, and cooperate }\end{array}$ & 96 & 18.22 & 295 & 55.98 & 69 & 13.09 & 13 & 2.47 & 54 & 10.25 \\
\hline $\begin{array}{l}\text { 16 Ability to use information } \\
\text { technology }\end{array}$ & 106 & 20.11 & 272 & 51.61 & 82 & 15.56 & 17 & 3.23 & 50 & 9.49 \\
\hline $\begin{array}{l}17 \text { Ability to do business in } \\
\text { English }\end{array}$ & 85 & 16.13 & 272 & 51.61 & 93 & 17.65 & 16 & 3.04 & 61 & 11.57 \\
\hline 18 Ability to function as a leader & 112 & 21.25 & 268 & 50.85 & 72 & 13.66 & 14 & 2.66 & 61 & 11.57 \\
\hline 19 Ability to debate & 136 & 25.81 & 285 & 54.08 & 47 & 8.92 & 10 & 1.90 & 49 & 9.30 \\
\hline 20 Ability to find good jobs & 138 & 26.19 & 263 & 49.91 & 59 & 11.20 & 8 & 1.52 & 59 & 11.20 \\
\hline $\begin{array}{l}21 \text { Ability to work with people } \\
\text { worldwide }\end{array}$ & 140 & 26.57 & 266 & 50.47 & 54 & 10.25 & 12 & 2.28 & 55 & 10.44 \\
\hline $\begin{array}{l}22 \text { Ability to search for } \\
\text { scholarships to study abroad to } \\
\text { develop your professionalism }\end{array}$ & 128 & 24.29 & 240 & 45.54 & 40 & 7.59 & 7 & 1.33 & 112 & 21.25 \\
\hline
\end{tabular}

